DOI: $10.2478 / \mathrm{v} 10014-011-0014-8$

COBISS Code 1.01

Agrovoc descriptors: databases, social sciences, agriculture, classification, nformation processing, nomenclature, terminology, information science, documentation, information processing, data collection, data processing, data analysis, information storage, information retrieval

Agris category code: $\mathrm{C} 30$

\title{
Topics related to social sciences by authors from Slovenia in agriculture-and-life-sciences database CAB Abstracts
}

\author{
Tomaž BARTOL ${ }^{1}$, Marjan HOČEVAR ${ }^{2}$
}

Received August 18, 2011; accepted September 15, 2011.

Delo je prispelo 18. avgusta 2011; sprejeto 15. septembra 2011.

\begin{abstract}
Documents related to social sciences are processed/indexed by several field-specific (e.g. Sociological Abstracts) and general (Web of Science, Scopus) bibliographic databases. These topics are scattered also among other specialized databases and information systems in agriculture, biomedicine, and other life-sciences, for example Agris, Agricola, FSTA, Medline (PubMed), etc. Agriculture can also involve social issues such as rural sociology, public services, settlements, demography, tourism (agritourism). Relevant documents may thus elude attention of researchers which seek information in a limited number of databases. We used CAB Abstracts (CABI/CAB International), the leading global database for agriculture, environment, veterinary sciences, applied economics, food science and nutrition. In a bibliometric/scientometric analysis, we used the classification based on subject categories CABICODES (CC), which enable identification of general research subject areas, in order to assess publishing patterns by researchers from Slovenia in 1991-2010. We assessed growth, and identified database records which had been classified with the social-sciences-related CC. We assessed co-classification or co-occurrence of these categories with other general subjects, such as Economics, Plant Science and Protection, Food Science and Produce, Animal Science, Forestry and Wood, Pathogen, Pest, Parasite and Weed Management, Soil Science, Human Health and Nutrition, Education, Extension, Information, Training, Natural Resources. 336 records were published by Slovenian authors, and classified with social sciences $\mathrm{CC}$ in CAB Abstracts. In total, 1313 different $\mathrm{CC}$ had been assigned to the records. The social-sciences-related research co-occurs with the following subject matter, in a decreasing order: economics, forestry/wood science, natural resources (e.g. water, meteorology, pollution), human biology/health/nutrition, food, plant, animal science/protection.
\end{abstract}

Keywords: agriculture, sociology, social sciences, bibliographic databases, information systems, subject headings, category codes, categories, indexing, co-occurrence, co-classification, $\mathrm{CAB}$ Abstracts, bibliometrics, scientometrics

\section{IZVLEČEK}

\section{DRUŽBOSLOVNA TEMATIKA V PRISPEVKIH SLOVENSKIH AVTORJEV PO PODATKIH BIOTEHNIŠKE/KMETIJSKE ZBIRKE CAB ABSTRACTS}

Dokumente $\mathrm{v}$ povezavi $\mathrm{z}$ družboslovjem oz. sociologijo obdelujejo in indeksirajo različne specializirane (npr. Sociological Abstracts) in splošne (Web of Science, Scopus) bibliografske podatkovne zbirke (baze podatkov). Ta tematika je razkropljena tudi med drugimi specializiranimi zbirkami in informacijskimi sistemi v kmetijstvu (biotehniki), biomedicini in drugih disciplinah, npr. Agris, Agricola, FSTA, Medline (PubMed). Kmetijstvo se navezuje na ruralno sociologijo (sociologijo podeželja), javne storitve, demografijo, naselja, turizem (kmečki turizem) ipd. Raziskovalci, ki uporabljajo samo določene zbirke, lahko spregledajo številne relevantne dokumente. V bibliometrični/scientometrični analizi smo uporabili zbirko $\mathrm{CAB}$ Abstracts (CABI/CAB International), ki je vodilna zbirka za kmetijstvo, okolje, veterino, uporabno ekonomiko, živilstvo in prehrano, in sicer glede na klasifikacijo, temelječo na predmetnih kategorijah CABICODES (CC), ki omogočajo identifikacijo splošnih raziskovalnih področij in na tem temelju ocenili objave avtorjev iz Slovenije v 1991-2010. Ocenili smo letno rast objav in identificirali vse zapise v zbirki, ki so bili klasificirani s kategorijami iz sekcije družboslovje (social sciences). Ovrednotili smo soklasifikacijo-sopojavnost teh kategorij $\mathrm{z}$ drugimi splošnimi kategorijami, kot so ekonomika, rastlinska

\footnotetext{
${ }^{1}$ University of Ljubljana, Biotechnical Faculty, Department of Agronomy, SI-1000 Ljubljana, Slovenia, Ph.D., Assoc. Prof., email: tomaz.bartol@bf.uni-lj.si

2 University of Ljubljana, Faculty of Social Sciences, SI-1000 Ljubljana, Slovenia, Ph.D., Assoc. Prof.
} 
pridelava in varstvo rastlin, živilstvo, znanost o živalih in varstvo živali, gozdarstvo in lesarstvo, bolezni, škodljivci in pleveli, pedologija, zdravje, biologija in prehrana ljudi, izobraževanje, svetovanje, informacije, naravni viri ipd. Slovenski avtorji so v tem obdobju objavili 336 dokumentov, ki so bili klasificirani z družboslovnimi kategorijami zbirke CAB. Ti dokumenti so bili skupno opremljeni s 1313 različnimi kategorijami. Družboslovna tematika se najbolj prepleta $\mathrm{z}$ ekonomiko, sledijo gozdarstvo/lesarstvo, naravni viri (npr. voda, meteorologija, onesnaževanje), zdravje, biologija in prehrana ljudi, živilstvo, rastlinska proizvodnja in varstvo ter živalska proizvodnja.

Ključne besede: kmetijstvo, biotehnika, sociologija, družboslovje, bibliografske podatkovne zbirke, informacijski sistemi, predmetne oznake, kategorije, indeksiranje, sopojavnost, soklasifikacija, CAB Abstracts, bibliometrija, scientometrija

\section{INTRODUCTION AND BACKGROUND}

In the age of an increasing interdisciplinary research it is getting progressively more difficult to identify relevant documents, on account of the scatter of information among many different resources. It is possible to employ general, global information systems, such as Web of Science (Thomson Reuters, formerly ISI) or SciVerse Scopus (Elsevier). These systems and respective databases place strong importance on tracking citations. But in order to carry out comprehensive searches, end-users need to consult also discipline-specific databases. These databases excel in complex classification of subject matter. Such additional analysis and organization of knowledge is performed by information professionals which take into account characteristics of each particular information system. Interdisciplinary topics are scattered across many different databases, served by particular systems of subject headings (descriptors, preferred terms, identifiers, category codes, classifications etc.). This is the case with many life-sciences or social-sciences subdisciplines. For example, the topics of agricultural economics or rural sociology can be scattered among social-sciences or agriculture-related information systems.

Social sciences are organized in several disciplinespecific databases, for example Sociological Abstracts. But some particular social-sciences-related research can also be strongly represented in agricultural databases, such as Agricola, Agris, CAB Abstracts or FSTA (Food Science and Technology Abstracts). Each of these systems is organized in a specific way. In our bibliometric (scientometric) analysis we wish to identify, on the example of authors from Slovenia, patterns of documents/publications which have been classified as pertaining to social sciences in an agricultural database. To this end, we will focus on the leading international database $\mathrm{CAB}$ Abstracts (CABI/CAB International) which contains several thousand agriculture-and-life-sciences-related documents by Slovenian authors. This database contains millions of records which are relevant not only to agriculture but also other topics in life sciences, such as environment, human development and health. We wish to assess the context of documents classified as social sciences also in relation to other research topics, such as animal, plant, forestry/wood and food sciences. At the same time we will also assess characteristics of the CABI classification system (CABICODES). This research thus also seeks to offer some methods for better search techniques.

CABI subject categories (CABICODES, henceforward $\mathrm{CC})$ were examined, in an early study, in order to identify literature on agricultural economics and rural sociology (Stanton, 1991). The use of CC in combination with keywords would lead to better searching precision (Greider, 2002; Stephens, 2002). $\mathrm{CC}$, along with some other classifications and vocabularies, were also used in classifying and describing learning resources on organic agriculture and agroecology (Ebner et al., 2009, Kastrantas et al., 2009). Some basic usage of Agris Subject Category Codes and $\mathrm{CC}$ was presented on an example of an agricultural journal by Bartol (2009). CAB Abstracts (henceforward CABA), and social-sciences databases, such as Sociological Abstracts (henceforward SocAb) or Social Science Citation Index have frequently been used to assess specific fields related to social sciences and economics, most notably agricultural economics, communications, consumers, public health, rural sociology, tourism, etc. SocAb and CABA were used in a research on the perception of health foods (Paquette, 2005). The scatter of journal literature in the field of agricultural economics and agribusiness was also investigated on the models of CABA, and some other information systems, such as Web of Knowledge, Google Scholar and EconLit (Salisbury and Takewade, 2006). Zumalt (2007) used CABA and Communication Abstracts to tackle agricultural communications and concluded that it is necessary to include also many other information resources to retrieve information in such a widely scattered field. Consumer perception of food labels was also investigated, on the examples of CABA 
and $\mathrm{SocAb}$, along with several other life sciences and social sciences databases (Grunert and Wills, 2007). Social Science Citation Index and CABA were compared with regard to the concepts in titles and abstracts (Pautaso, 2010). CABA has frequently been used as a good bibliographic source of tourism-related scholarly information. CABA was identified as an important resource for the field of leisure and tourism in an early study that also listed SocAb (Leighfield, 1987). Another study employed CABA and database ABIInform to assess information on travel and tourism (Ojala, 1990). CABA was also identified as an important source of information related to sport and tourism by Allen (2005). Leading scholarly tourism journals were assessed through CABA, Scopus and JSTOR in research by Baggio et al. (2008). Tourism research communications through journals, on the example of CABA, SocAb, Social Science Citation
Index, and some other databases in the field of social sciences, were assessed by Xiao and Smith (2010). $\mathrm{CABA}$ and SocAb were sometimes used to evaluate national production, and were identified as important resources for information on public health-related scientific production in Latin America (Coimbra and Carlos, 1999). CABA and SocAb, and several other databases were also compared with regard to the scientific production by research institutions in the capital cities of the new European Union countries (Bartol and Hocevar, 2005). Coverage of national production in Mexico was also investigated through CAB Abstracts, Social Science Citation Index (SSCI), and some other databases (Bravo-Vinaja and SanzCasado, 2008)

\section{MATERIALS AND METHODS}

We employed database CAB Abstracts and its classification scheme CABICODES in order to assess publishing patterns by researchers from Slovenia in the period 1991-2010. We placed emphasis on topics related to social sciences, which we also investigated in relation to other major research topics indexed by $\mathrm{CAB}$ Abstracts (henceforward $\mathrm{CABA}$ ). CABA is compiled by $\mathrm{CAB}$ International (CABI), and is the most comprehensive global database involving agriculture (animal and plant sciences, forestry), environment, veterinary sciences, applied economics, food science and nutrition (CAB, 2011). It contains 6.3 million records from 1973 onwards. 300,000 new records are added each year. The database includes documents from international (English-language) as well as non-Englishlanguage journals and publications from over 116 countries in 50 languages. English abstracts are included in most records. All records are also indexed and classified with indexing terms and classification codes (CABICODES, henceforward $\mathrm{CC}$ or codes). There are more than 90,000 indexing terms (descriptors or preferred terms, keywords) in CABI's controlled indexing vocabulary (CAB Thesaurus). These terms are structured on several hierarchical levels and are used to describe very specific subject concepts. The codes, which are divided into 23 subject areas or sections, however, are used for subject classification of broad or general concepts. Each section includes codes that divide a concept into more specific subjects (Advanced, 2011; Ison, 2011). The utility of CABICODES is very useful in retrieving major subjects or topics which would be difficult to identify with indexing terms (keywords) alone. The codes consist of double letters in combination with three digits, for example BB500 - History and Biography, FF061 - Plant Nutrition, LL300 - Animal Behaviour, etc. In total, there are some 250 codes. The CC categories are based on the broad classification system used in the Agricola database (Subject Category Codes, NALNational Agricultural Library) and AGRIS database (Agris
Subject Categories, FAO of the United Nations), adapted for the subject emphasis of the CAB Abstracts database.

In our study we used these codes to identify different topics classified as pertaining to social sciences in the CABA database, which is principally an agricultural database. In the database we retrieved records co(authored) by researchers from Slovenia, and which had been in the period 1991-2010 classified with any of the codes pertaining to the section UU (Social Sciences). Currently, there exist 17 specific codes in the section UU, such as Housing and Settlement, Demography, Tourism and Travel etc. Nine (9) codes, such as Urban Regeneration, Community Development, Recreation and Sport, etc. were discontinued in 2000. Most have been substituted with other codes. For example, Recreation and Sport (UU620) has been replaced with Sport and Recreational Activities (UU625). Our study, however, spanned two decades so we employed all the codes that had been during this period assigned to the documents. Namely, older, discontinued codes must currently still be used to retrieve older documents in back-file. These UU section codes are later assessed in the Figure 2.

We set up an experimental database, based on the downloaded records, in order to carry out further analyses. We identified all codes pertaining to the section UU. We assessed the growth of records classified with any of the codes from the section UU. We identified the other 22 major categories or major sections, such as Economics... (EE), Forestry... (KK), Plant Science... (FF), Animal Science... (LL), and assessed cooccurrence or co-classification of the UU codes with any of these 22 major sections. 


\section{RESULTS AND DISCUSSION}

In the period 1991-2010, there were 213,060 records in CABA which had been classified with the codes pertaining to the section UU (Social Sciences). In the same period there were 9,013 records affiliated with the authors from Slovenia. The section UU was assigned to 336 records which had been co(authored) by researchers from Slovenia. In the initial ten-year period, up to 15 yearly records were classified with the UU codes. In the more recent period, almost twice as many records are classified with these codes. Noticeable increase can be observed after 2002 (Figure 1). Some decrease in 2010 can probably be attributed to a delay in inclusion of records in the database.

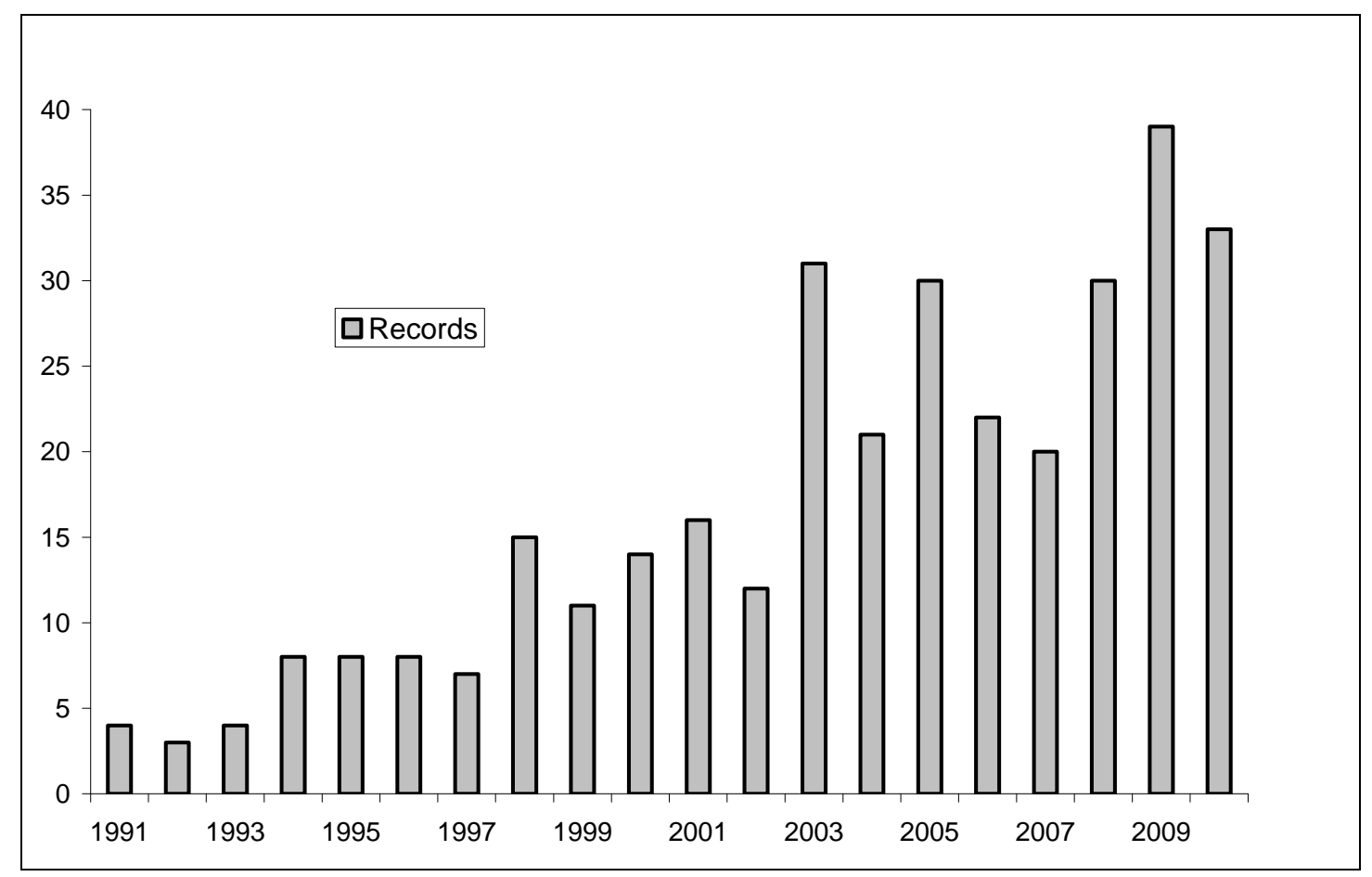

Figure 1: Growth of documents published by Slovenian authors in the period 1991-2010, as classified with any social-sciences-related CABICODE (UU)

In CABA several codes are usually assigned to each document. Sometimes, a document is also classified with different codes from the same section so in our case 430 different UU codes were assigned to the 336 records. These UU codes are presented in the Figure 2. As many as 108 documents were classified with the code Social Psychology and Social Anthropology [UU485]. This is a rather general concept which can be attributed to many different topics. It is followed by 88 documents classified as Tourism and Travel [UU700]. This is a more specific code than UU485. We can also observe that some special emphasis is placed on selected topics or concepts. There are several codes which denote the concepts of leisure, sport and tourism. This subject matter is namely an important subset of the $\mathrm{CAB}$ Abstracts database. Two particular codes are dedicated to rural topics, Rural Development [UU850] and Rural Sociology [UU800]. The two concepts are nevertheless very related but the later concept [UU800] is more general in meaning.

Some codes were discontinued in 2000, as we mentioned before. These codes are in the Figure 2 marked with (D). They must, however, still be used for retrieval of older documents. 


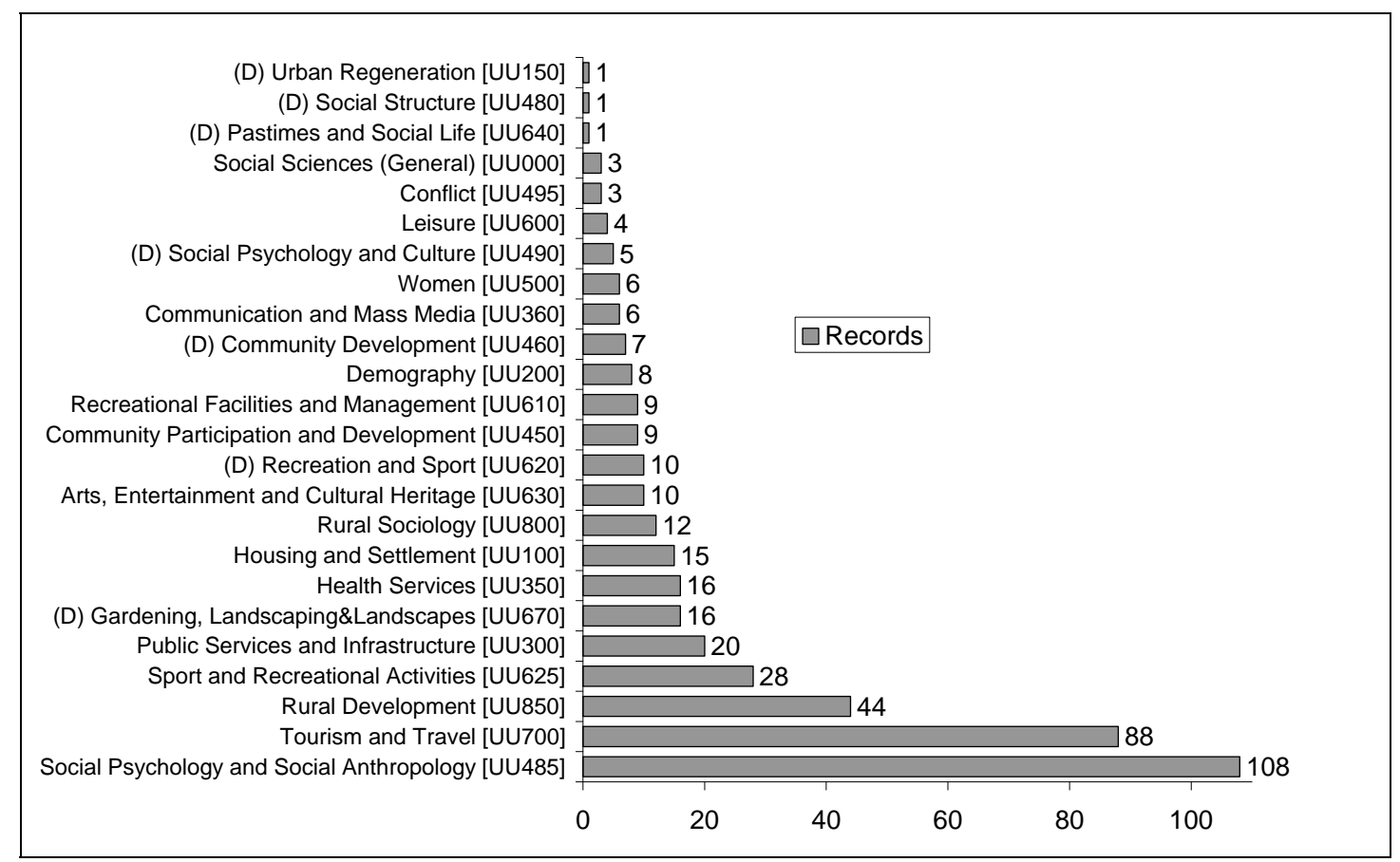

Figure 2: Specific social-sciences-related CABICODES, assigned to document published by Slovenian authors in the period 1991-2010

In our further analysis we measured the level of interdisciplinarity by way of co-classification or cooccurrence of Social Sciences [UU] codes with the codes from the other 22 sections from the CABICODE system, such as Economics [EE], Forestry and Wood Science [KK], Plant Science, Protection [FF], Animal Science, Protection [LL] etc. (Figure 2, Table 1). Altogether, 1314 different codes were assigned to the 336 records. Thus, on average, every document was classified with four different codes. Some 140 records were classified with only three codes or fewer. However, ten documents were classified with at least 10 codes, and one document with as many as 13 different codes.

It is interesting to examine the document which was classified with 13 different codes. This is a monograph contribution with a rather general title 'Slovenia' and was published in an international book dedicated to Mediterranean forests. The document was classified with the following CABICODES:

Biological Resources (Plant) [PP720], Social Psychology and Social Anthropology [UU485], Sport and Recreational Activities [UU625], Agencies and Organizations [DD100], Forestry Economics [EE112], Policy and Planning [EE120], Structure, Ownership and Tenure [EE165], International Trade [EE600],
Labour and Employment [EE900], Forests and Forest Trees (Biology and Ecology) [KK100], Silviculture and Forest Management [KK110], Non-wood Forest Products [KK540], Land Resources [PP300].

Such codes can serve as a powerful tool for identification of topics in a particular book, especially in the case of general titles which are not sufficiently indicative of a book content.

We mentioned before that different codes from the same section can be assigned to one document. This is shown in the Table 1 where the second column (Occ.) presents all occurrences of a particular code in the 336 records. The third column (Records) presents the records which were classified with any of the codes in the section. The records are also presented in Figure 2. The difference is the highest in Economics [EE] where there are 152 records, classified with 319 different codes. So, on average, two different codes from the EE group were assigned to EE-classified records.

In the fourth column of the Table 1 we present coclassification of all major sections which co-occurr with the UU codes which can in this case serve as a measure of interdisciplinarity. In this model, all major sections from the CABICODE list co-occur with the UU codes, except for the major section Medical and Veterinary ... 
Records [TT] which was discontinued already in 1995. UU-section codes co-occur with the highest rate $(0,45$ or $45 \%$ ) with the codes from the section on Economics [EE] (Table 1). The value 0,45 indicates that 152 among the 336 total UU-records contain at least one EE code $(152 / 336=0,45)$. This somehow high value can be explained. Namely, some topics in economics are in fact strongly associated with social sciences. In the section [EE] there exist such subsections as Aid [EE125], Structure, Ownership and Tenure [EE165], or Income and Poverty [EE950]. In such cases it may be difficult to disambiguate 'social' topics from purely 'economical' ones. Therefore, both UU and EE sections are frequently assigned by information professionals to a particular document in order to improve search results (search recall). Such assessment of co-occurrence is probably more relevant in the case of specific agricultural disciplines or technologies, and can imply a certain level of interdisciplinarity. There are 119 Forestry and Wood Science [KK] records, or $35 \%$, among the 336 records. The codes for Natural Resources [PP] come about in $24 \%$ of records. But the $[\mathrm{PP}]$ is a rather general section which contains quite diverse subsections such as Energy [PP100], Water Resources [PP200], Land Resources [PP300], Wetlands [PP320], Grasslands and Rangelands [PP350], Meteorology and Climate [PP500], Pollution and Degradation [PP600] or Biological Resources [PP700]. Food science is represented in 26 records (8\%), however, some important information on social aspects of human nutrition may also be contained in the section Human Health, Biology, Nutrition [VV] which accounts for $10 \%$ of records. Plant science and protection [FF] occurs in $9 \%$, and Animal science and protection [LL] in $5 \%$ of cases. Some codes, such as those in the section Pathogen, Pest, Parasite and Weed Management [HH] apply to plant-, animal- or humanrelated topics alike.

Some major sections exhibit a rather low co-occurrence with the UU codes. Sections Non-food/Non-feed Plant Products [SS], Forage and Feed Products (Non-human) $[\mathrm{RR}]$ and Aquaculture (Animals) [MM] thus come about in less than $1 \%$ of UU-classified records.

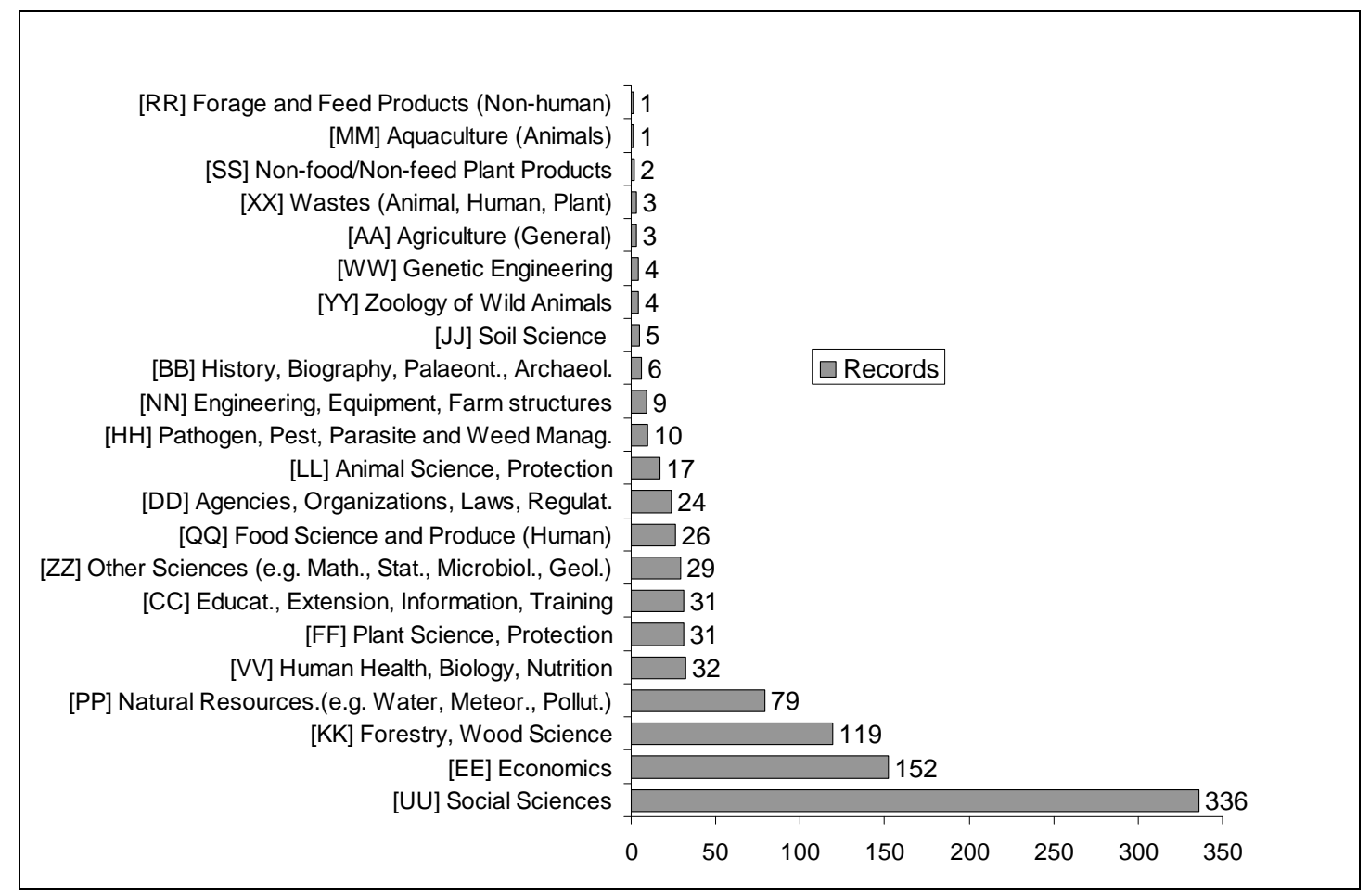

Figure 3: General CABICODES, assigned to document published by Slovenian authors in the period 1991-2010, which occur along social-sciences CABICODES. 
Table 1: General CABICODES, all occurrences of Codes (Occ.), records (documents) classified with the Codes, cooccurrence of other Codes with UU Codes.

\begin{tabular}{llll}
\hline Category (CABICODES) & Occ. & Records & Co-occ. \\
\hline [UU] Social Sciences & 430 & 336 & \\
[EE] Economics & 319 & 152 & 0.45 \\
[KK] Forestry, Wood Science & 145 & 119 & 0.35 \\
[PP] Natural Resources.(e.g. Water, Meteor., Pollut.) & 106 & 79 & 0.24 \\
[VV] Human Health, Biology, Nutrition & 44 & 32 & 0.10 \\
[FF] Plant Science, Protection & 52 & 31 & 0.09 \\
[CC] Educat., Extension, Information, Training & 34 & 31 & 0.09 \\
[ZZ] Other Sciences (e.g. Stat., Microbiol., Geol.) & 33 & 29 & 0.09 \\
[QQ] Food Science and Produce (Human) & 35 & 26 & 0.08 \\
[DD] Agencies, Organizations, Laws, Regulat. & 26 & 24 & 0.07 \\
[LL] Animal Science, Protection & 32 & 17 & 0.05 \\
[HH] Pathogen, Pest, Parasite and Weed Manag. & 14 & 10 & 0.03 \\
[NN] Engineering, Equipment, Farm structures & 10 & 9 & 0.03 \\
[BB] History, Biography, Palaeont., Archaeol. & 6 & 6 & 0.02 \\
[JJ] Soil Science & 7 & 5 & 0.01 \\
[YY] Zoology of Wild Animals & 6 & 4 & 0.01 \\
[WW] Genetic Engineering & 4 & 4 & 0.01 \\
[AA] Agriculture (General) & 3 & 3 & 0.01 \\
[XX] Wastes (Animal, Human, Plant) & 3 & 3 & 0.01 \\
[SS] Non-food/Non-feed Plant Products & 2 & 2 & 0.01 \\
[MM] Aquaculture (Animals) & 1 & 1 & 0.00 \\
[RR] Forage and Feed Products (Non-human) & 1 & 1 & 0.00 \\
\hline
\end{tabular}

\section{CONCLUSIONS}

Scientific information is scattered in an increasing number of information resources and databases, also on account of a growth in interdisciplinary research. All databases, however, exhibit some particular characteristics so a certain level of information expertise is required for the discovery of this knowledge. The many different research topics within the scope of social sciences are scattered among some major life-sciences databases. This is for example the case with agricultural economics, communications, consumers, public health, rural sociology, rural tourism etc. These topics are strongly represented in agricultural databases, such as CAB Abstracts, which served as a research model in our study. Because many authors publish social-sciencesrelated research in agriculture-related publications, such document may escape the attention of end-users which consider social-sciences databases only.

General subject categories may serve as a useful tool for retrieval of major subjects or topics which would be difficult to locate with very specific keywords. Such codes can be, for example, especially practical in the case of books or book-chapters which sometimes provide only very general titles. This was shown on the example of the chapter published in a book dedicated to Mediterranean forests, and which was classified with as many as 13 different categories or codes. Subject categories can thus serve, along with keywords (descriptors) and abstracts, as a valuable tool for knowledge discovery. Our research identified some patterns in interdisciplinary research by scientists from Slovenia. The main topics in the UU category are rather diverse even though they are all classified as social sciences. Our subsequent examination of the records in an experimental database shows that there are in fact several rather consistent research themes, related to economics, health, sport and tourism, and several general agricultural disciplines. If considering the particular broader agricultural disciplines, we found that an important share of social-sciences-related research was related to forestry, food and human nutrition, followed by plant and animal sciences. It also possible to identify the social aspects of some particular fields, such as meteorology or pollution-related issues. 
It is important to point out that all codes have the same classification value. Some are rather general, such as Social Psychology and Social Anthropology [UU485] and are less indicative of a specific topic in a document, and are thus also less applicable in an end-user searching. Some other codes, however, such as Tourism and Travel [UU700], are more specific and can be used with a better search precision. On the other hand, there are several codes, which denote associated concept, such as Rural Development [UU850] or Rural Sociology [UU800]. User wishing to identify relevant documents should thus combine several topically similar codes with a Boolean OR in order to improve search results. Users wishing to find documents preceding the year 2000 must pay special attention to the fact that some new codes were introduced in that year. Most new codes replace previous similar concepts but older codes should still be used for the retrieval of older information.

We need to mention that information professionals and specialists play a major role in assigning classification codes and descriptors to the documents in databases. Each database or information system possesses a particular subject system which is database-specific and standardized on some set principles. Subjective influence of information professionals, which assign subject headings, can nevertheless not be excluded. But the issues of classification subjectivity are a research field in its own right and could not be tackled in this analysis which was based on state-of-the-art classification system by one information service (CABI). We have thus employed this system according to the set of fields and headings which are constant in this database, thus facilitating a possible further research and comparison of our results by other authors. At the end we wish to conclude that the end-users should pay more attention to the selection of information resources, especially in the case of interdisciplinary research which is scattered among many information systems. Users need to get acquainted with characteristics and classification principles in databases if they wish to use information systems to the full capacity.

\section{REFERENCES}

Advanced Searching of CAB Abstracts with OvidSP. 2011. Available at: http://www.cabi.org/Uploads/File/ CABIDotOrg/User\%20Guides/Ovid/advancedsearchingo fcababstractswithovidspadvancedsearch.pdf (Accessed August 25, 2011).

Allen, M.B. 2005. Sports, exercise, and fitness: a guide to reference and information sources. Westport and London. Libraries Unlimited. 287 pp.

Baggio, R., Scott, N. and Arcodia, C. 2008. Collaboration in the events literature: a co-authorship network study. EUTO 2008 - Attractions and events as catalysts for regeneration and social change. University of Nottingham, Sept 24-25: p. 1-16.

Bartol, T. 2009. Assessment of classification and indexing of an agricultural journal, based on metadata in AGRIS and $\mathrm{CAB}$ Abstracts databases. International Journal of Metadata, Semantics and Ontologies, 4(1/2): 4-12.

Bartol, T. and Hocevar, M. 2005. The capital cities of the ten new European Union countries in selected bibliographic databases. Scientometrics, 65(2): 173-187.

Bravo-Vinaja, A. and Sanz-Casado, E. 2008. Bibliometric analysis of the Mexican scientific production in agricultural sciences during the years 1983-2002 [Análisis bibliométrico de la producción científica de México en ciencias agrícolas durante el periodo 19832002]. Revista Fitotecnia Mexicana, 31(3): 187-194.

CAB Abstracts - Overview. 2011. Available at: http://www.cabi.org/default.aspx? site $=170$ \&page $=1016 \&$ pid=125 (Accessed August 25, 2011).
Coimbra Jr., C.E.A. 1999. Scientific production in public health and the international literature bases [Produção científica em saúde pública e as bases bibliográficas internacionais]. Cadernos de Saúde Pública, 15(4): 883888 .

Ebner, H.; Manouselis, N.; Palmer, M.; Enoksson, F.; Palavitsinis, N.; Kastrantas, K.; and Naeve, A. 2009. Learning Object Annotation for Agricultural Learning Repositories. In: Ninth IEEE International Conference on Advanced Learning Technologies. Riga. July 15- 17: 438 -442 .

Greider, A. P. 2002. An introduction to the literature and general sources. In.: Using the Agricultural, Environmental, and Food Literature (eds. Hutchinson, B. S. and Greider, A. P.). New York and Basel, Marcel Dekker: 1-12.

Grunert, K.G. and Wills, J.M. 2007. A review of European research on consumer response to nutrition information on food labels. Journal of Public Health, 15: 385-399.

Ison, C. 2011. CAB Abstracts on CAB Direct. Knowledge for life. www.cabi.org. PPT presentation.

Kastrantas, K., Palavitsinis, N., Manouselis, N., Palmer, M., Ebner, H. and Sanchez-Alonso, S. 2009. Educational Metadata for Organic.Edunet Learning Objects (Multilingual). Organic.Edunet project. eContentplus: $141 \mathrm{pp}$.

Leighfield, M. 1987. Leisure 2001: Information for a Leisure Society. European Journal of Education, 22(3/4): 321325. 
Ojala, M. 1990. Finding information on the travel/tourism industry. Database, 13(3): 80-83.

Paquette, M.C. 2005. Perceptions of Healthy Eating. State of Knowledge and Research Gaps. Canadian Journal of Public Health, 96 (suppl. 3): S15-S19.

Pautasso, M. 2010. Worsening file-drawer problem in the abstracts of natural, medical and social science databases. Scientometrics, 85(1): 193-202.

Salisbury, L and Tekawade, A. 2006. Where is agricultural economics and agribusiness research information published and indexed? A comparison of coverage in Web of Knowledge, Cab abstracts, EconLit, and Google Scholar. Journal of Agricultural and Food Information, 7(2/3): 125-143.
Stanton, F. B. 1991. Characteristics of Agricultural Economics Literature. In: Agricultural economics and rural sociology: the contemporary core literature (ed. Olsen, W.C.). Ithaca, Cornell Univ Press: 12-21.

Stephens, G. 2002. Animal Health and Veterinary Sciences. In.: Using the Agricultural, Environmental, and Food Literature (eds. Hutchinson, B. S . and Greider, A. P.). New York, Marcel Dekker and Basel: 66-119.

Xiao, H. and Smith, S.L.J. 2010. Professional communication in an applied tourism research community. Tourism Management, 31(3): 402-411.

Zumalt, J.R. 2007. Identifying the Core Periodical Literature of the Agricultural Communications Documentation Center. Journal of Agricultural and Food Information, 8(3): 43-63. 